\title{
Dual fuelling SI engine with alcohol and gasoline
}

\begin{abstract}
The Department of Internal Combustion Engines and Vehicles, Technical University of Bielsko-Biala has carried out work on alternative fuels in the area of dual-fueling of SI engines. The paper presents the concept of dual fuel (alcohol and gasoline) MPI injected spark-ignition engine using a fuel mixing device. The solution consists in mixing the fuel (gasoline and alcohol) before or in the fuel rail, which ensures a variable share of alcohol in the mixture in the range from $0 \div 100 \%$, depending on the engine operating conditions (engine revolutions and load), and its thermal state. The fuels are delivered to the mixing chamber through the solenoid valves that allow a proper selection of the proportion of alcohol and gasoline. The pre-prepared mixture is injected through the original injectors to the intake manifold, around the intake valve. This paper presents the prototype of the mixer that allows mixing of the gasoline and alcohol in any proportion using a PWM.
\end{abstract}

Key words: dual fuel engine, alcohol, mixer, emissions, thermal efficiency, thermal load

\section{Dwupaliwowe zasilanie silnika o zapłonie iskrowym mieszaniną alkoholu i benzyny}

W Katedrze Silników Spalinowych i Pojazdów Akademii Techniczno-Humanistycznej w Bielsku-Białej prowadzone sa prace dotyczace wykorzystania paliw alternatywnych $w$ ramach dwupaliwowego zasilania silników ZI. W artykule przedstawiono koncepcję dwupaliwowego zasilania silnika o zapłonie iskrowym z wielopunktowym wtryskiem alkoholu $i$ benzyny za pomoca mieszalnika paliw. Przedstawione rozwiazanie polega na mieszaniu paliw (benzyny $i$ alkoholu) przed kolektorem paliwowym lub w kolektorze, co zapewnia zmienne udziały alkoholu w zakresie od $0 \div 100 \%$, zależnie od warunków pracy silnika (prędkości obrotowej i obciązenia) oraz jego stanu cieplnego. Paliwa dostarczane sa do komory mieszania i za pomoca zaworów elektromagnetycznych umożliwiają odpowiedni dobór proporcji alkoholu $i$ benzyny. Przygotowana wstępnie mieszanina wtryskiwana jest przez oryginalne wtryskiwacze silnika do kolektora, w okolice zaworu. W niniejszej pracy przedstawiono badania prototypowego mieszalnika umożliwiajacego mieszanie benzyny $i$ alkoholu $w$ dowolnych proporcjach za pomoca sterowania impulsami PWM.

Słowa kluczowe: silnik dwupaliwowy, alkohol, mieszalnik, toksyczność spalin, sprawność ogólna, obciązenie cieplne

\section{Introduction}

The fueling of spark ignition engines with alcohols has a long established tradition. The concept was born in the period of World War I in the field of military aviation and then between the wars in sports engines. The main idea behind alcohol addition to the fuel, in most cases ethanol, was to increase the octane number of the fuel and reduce knocking in engines of high power/capacity ratio. The positive features of ethanol and methanol led to a development of engines fueled with alcohol exclusively in the period between the world wars. Also in Poland, shortly after the war many engines were fueled with alcohol exclusively (mostly ethanol) $[1,3,6,12]$. The 1970 s of the $20^{\text {th }}$ century saw an increased interest in alcohol fueling, which was caused by a serious fuel crisis and abruptly skyrocketing crude oil prices. The fact that the content of lead compounds (additives boosting the fuel octane number) was limited in the fuel also contributed to the situation. In Europe the engineers began to use mixtures of gasoline and alcohol, chiefly due to the need of boosting the fuel octane number. $[2,4,7,12,14]$. The basic problem of this type of fueling was the phenomenon of splitting of these mixtures at lower temperatures and in the presence of water. For this reason the alcohol content in the mixtures was limited to a few percent. This content could be increased through the use of stabilizers such as ethers,

\section{Wstęp}

Zasilanie silników o zapłonie iskrowym alkoholami ma długą tradycję. Zostało ono zapoczątkowane w okresie I wojny światowej w lotnictwie wojskowym, a następnie w okresie międzywojennym w silnikach sportowych. Głównym celem dodatku alkoholu, w przeważającej większości etylowego, było zwiększenie liczby oktanowej paliwa i przeciwdziałanie spalaniu stukowemu w wysilonych silnikach. Pozytywne cechy alkoholu etylowego i metylowego spowodowały powstanie w okresie międzywojennym konstrukcji silników zasilanych samymi alkoholami. Również w Polsce w pierwszych latach po II Wojnie eksploatowano dużą liczbą silników zasilanych samym alkoholem, głównie etylowym[1, 3, 6, 12]. Ponowne zainteresowanie alkoholami wystąpiło w latach siedemdziesiątych ubiegłego wieku i było spowodowane dużym kryzysem paliwowym oraz gwałtownym wzrostem cen ropy naftowej. Nie bez znaczenia było również ograniczenie stosowania związków ołowiu jako dodatków zwiększających liczbę oktanową benzyn. W Europie zaczęto wtedy stosować mieszaniny benzyny i alkoholu, głównie ze względu na potrzebę zwiększenia jej liczby oktanowej $[2,4,7,12,14]$. Podstawowym problemem tego zasilania było jednak zjawisko rozwarstwienia mieszanin w niskich temperaturach i w obecności wody. $\mathrm{Z}$ tego powodu zawartość alkoholu w mieszaninach była 

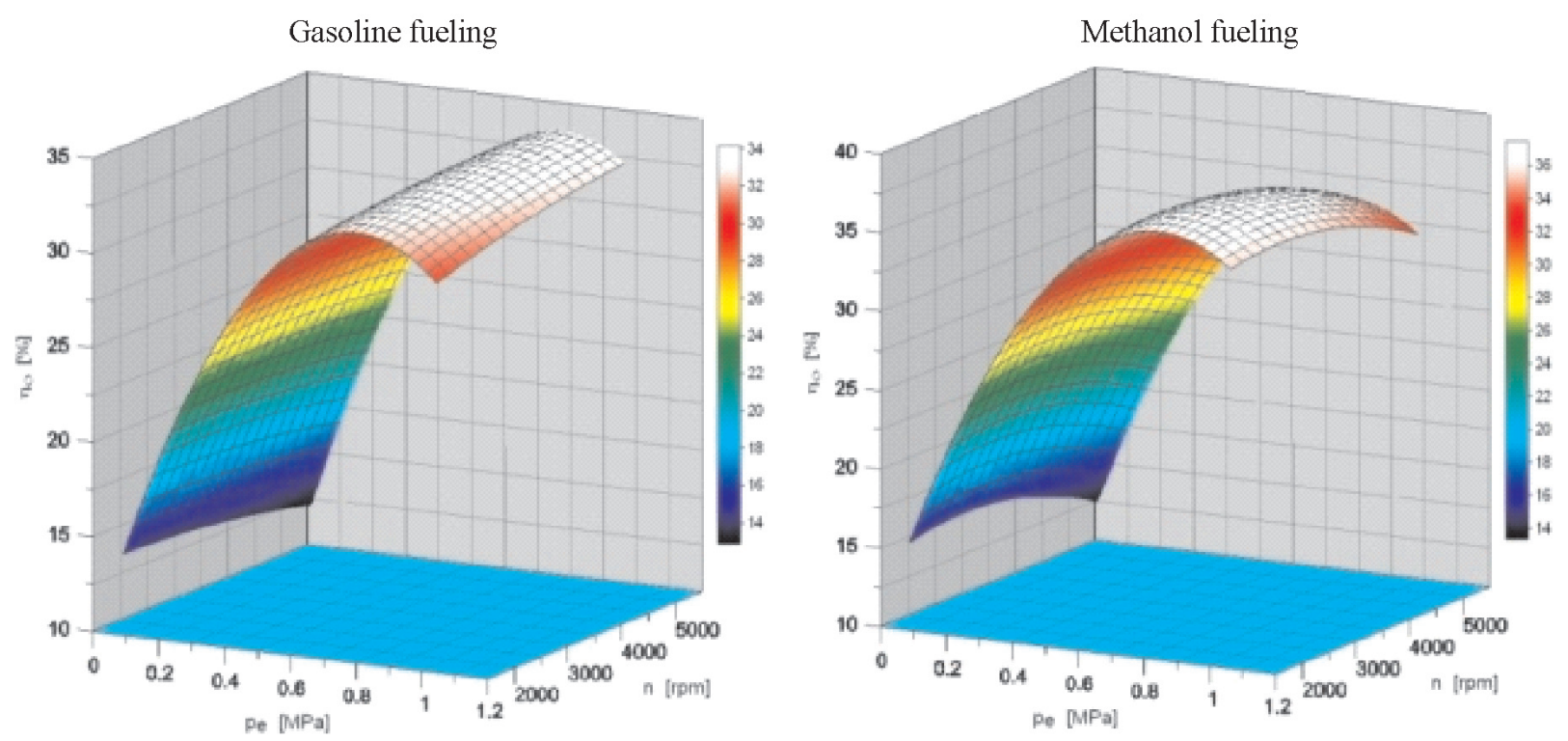

Fig. 1. Comparison of thermal efficiency of the Fiat 1100MPI engine fueled with gasoline and methanol only

Rys.1. Porównanie sprawności silnika FIAT 1100 zasilanego metanolem i benzyna

yet even that additive could not increase the alcohol content more than several percent by volume. At that time this was a serious problem when launching this type of fuel to the market. Much more advantageous is to use this fuel as an independent one as it ensures high knocking resistance, thus, enabling to increase the compression ratio, overall efficiency and unit engine power. Fig. 1 presents the comparison of the overall efficiency of the FIAT engine 1100 MPI fueled with gasoline and methanol [12].

The fueling of spark ignition engines with mixtures containing alcohol can be divided into several types:

- The mixture of gasoline and alcohol with the alcohol content $<\mathbf{8 \%}$ : The alcohol is added to a hydrocarbon base fuel as an additive increasing the fuel octane number. Depending on the amount of the additive such mixtures can be used all year (low additive content) or seasonally (higher additive content). Carburetor or injection systems with oxygen sensors do not need alignment in that case.

- The mixture of gasoline and alcohol with the alcohol content $<\mathbf{1 6}(\mathbf{2 0}) \%$ : Higher alcohol content is realizable as a three part additive with the addition of ether as the stabilizer. The most frequently used stabilizer is ether (methyl-tert-butyl). The mixtures (gasoline-alcohol-ether) do not split at lower temperatures in winters typical of the European climate. The fuel system with the addition of alcohol $>12 \%$ requires alignments.

- An injection of the emulsion of gasoline alcohol emulsion 'before the engine': This solution can be applied in both gasoline and diesel engines. Gasoline or diesel oil is mixed with the alcohol in a mixer (homogenizer) just prior to injection. A standard fuel system injects the emulsion to the intake manifold or directly into the cylinder. A short duration of the emulsion state does not lead to splitting.

- Separate injection of the fuels through two gasoline and alcohol injectors. This solution requires a special ograniczona do kilku procent. Zawartość tę można było zwiększyć dzięki zastosowaniu stabilizatorów takich jak etery, jednak i wtedy dodatek alkoholu nie przekraczał kilkunastu procent objętościowych. Stanowiło to w tamtym okresie znaczne utrudnienie przy wprowadzaniu tego paliwa do użytku. Korzystniejsze jest stosowanie alkoholu jako paliwa samoistnego, bowiem pozwala ono w pełni wykorzystać dużą odporność przeciwstukową alkoholu, umożliwiającą zwiększenie stopnia sprężania i wzrost sprawności ogólnej mocy jednostkowej silnika. Na rysunku 1 przedstawiono porównanie sprawności ogólnej silnika FIAT 1100MPI zasilanego benzyną i metanolem [12].

Zasilanie silników ZI mieszaninami z udziałem alkoholu można podzielić na kilka odmian:

- Mieszanina benzyna-alkohol o udziale alkoholu $<8 \%$ :

Alkohol jest dodawany do węglowodorowego paliwa bazowego jako domieszka podnosząca liczbę oktanową paliwa. W zależności od wielkości dodatku, paliwa takie mogą być zużywane przez cały rok (mały dodatek alkoholu) lub sezonowo (większy dodatek alkoholu). Gaźniki lub system wtryskowy z sondą lambda nie wymagają wtedy żadnych zmian regulacyjnych.

- Mieszanina benzyna-alkohol o udziale alkoholu < 16(20)\%: Większe zawartości alkoholu możliwe są jako dodatki trójskładnikowe z zastosowaniem eteru jako stabilizatora. Najczęściej stosowanym stabilizatorem jest eter (metylo-tert-butylowy). Mieszaniny (benzyna-alkohol-eter) nie rozwarstwiają się przy obniżeniu temperatury w zimie $\mathrm{w}$ granicach spotykanych w europejskiej strefie klimatycznej. Układ zasilania przy dodatku alkoholu $>12 \%$ wymaga $\mathrm{z}$ reguły zmian regulacyjnych.

- Wtrysk emulsji benzyna-alkohol przygotowanej przed silnikiem: Rozwiązanie to może być stosowane zarówno w silnikach ZI, jak i ZS. Benzyna lub olej napędowy mieszane są z alkoholem w mieszalniku (homogenizatorze) 
air intake manifold designed to allow for the trajectory of the sprays of the atomized fuels from both injectors.

A common application of multipoint injection of light fuels creates new possibilities of use of a variety of fuel feed strategies of alternative fuels. Both methanol and ethanol can be used in gasoline engines as independently applied fuels. Yet, the use of pure alcohols generates certain difficulties related to the engine operation at cold start and the necessity to heat the intake manifold in engines operating at temperatures lower than $10 \mathrm{oC}$, particularly when the engine is still heating up. For this reason it seems justified to apply dual fuel (gasoline and alcohol) systems similarly to commonly used LPG systems. The performance of engines fitted with such systems depends on the proper control of the fuel system and it becomes necessary to fit such engines with electronic control units and develop strategic, operating and aligning procedures for all the ranges of their operation. It is noteworthy that this trend in fueling is currently investigated by Volvo and Ford, which is confirmed in literature [10, 11]. Bosch has developed a technology of dual fueling of spark ignition engines (gasoline alcohol or their mixtures [17]. The injection system by Bosch enables a formation of the alcohol and gasoline mixtures in any given proportions of both of the fuels. The Bosch Motronic Flex-Fuel system, based on the oxygen content in the exhaust gases determined the amount of alcohol and the engine control unit adjust the parameters of injection and ignition to a given fuel composition.

\section{Description of the fueling system}

In the chair of combustion engines and vehicle at the Technical University of Bielsko-Biała scientists work on

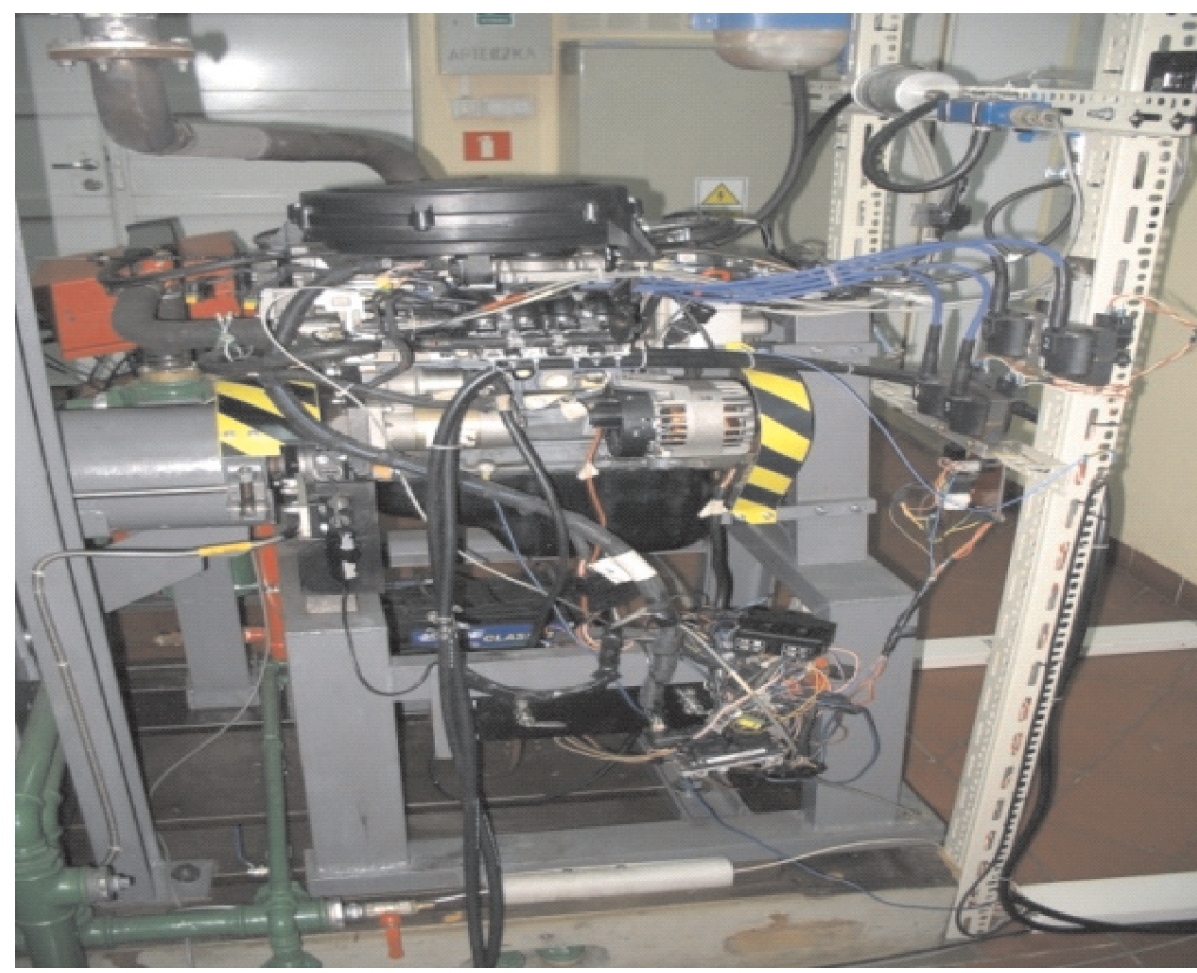

Fig. 2. The engine test bed - Fiat 1100 MPI

Rys. 2. Stanowisko badawcze silnika Fiat 1100 MPI tuż przed wtryskiem. Standardowa aparatura paliwowa wtryskuje emulsję do kolektora dolotowego lub bezpośrednio do cylindra. Krótki czas przebywania emulsji nie powoduje rozwarstwiania się paliw.

- Wtrysk oddzielny paliw przez dwa wtryskiwacze: jeden dla benzyny, drugi dla alkoholu. Rozwiązanie to wymaga budowy specjalnego kolektora dolotowego powietrza, w którym powinna być uwzględniona trajektoria strugi rozpylonych paliw z obydwu wtryskiwaczy.

Powszechne stosowanie wielopunktowego wtrysku paliw lekkich stwarza nowe możliwości stosowania różnych strategii zasilania wykorzystujących paliwa alternatywne. Zarówno alkohol metylowy, jak i etylowy mogą być stosowane w silnikach o zapłonie iskrowym jako paliwa samoistne. Stosowanie czystych alkoholi w tych silnikach stwarza jednak pewne trudności eksploatacyjne, polegające na utrudnionym rozruchu oraz konieczności podgrzewania kolektora dolotowego w silniku pracującym w niskich temperaturach, niższych od $10{ }^{\circ} \mathrm{C}$, szczególnie w fazie nagrzewania silnika. Z tego powodu wydaje się uzasadnione stosowanie $\mathrm{w}$ silnikach z zapłonem iskrowym układów dwupaliwowego zasilania benzyną i alkoholem, podobnie jak w powszechnie stosowanych układach zasilania LPG. Osiągi tak zasilanych dwupaliwowych silników są uzależnione od właściwego sterowania układu zasilania paliwem i koniecznością staje się wspomaganie silników elektronicznymi układami sterującymi oraz opracowanie procedur strategicznych, operacyjnych i regulacyjnych dotyczących wszystkich zakresów ich pracy. Należy zaznaczyć, że ten kierunek zasilania jest obecnie badany przez firmy Volvo i Ford, o czym świadczą doniesienia literaturowe $[10,11]$. Firma Bosch opracowała technologie dwupaliwowego zasilania silnika ZI benzyną, alkoholem lub mieszaniną obu paliw [17]. System wtryskowy firmy Bosch umożliwia dowolne mieszanie obu paliw. System Bosch Motronic Flex-Fuel na podstawie zawartości tlenu w spalinach określa zawartość alkoholu w paliwie, a układ sterowania silnika dostosowuje parametry zapłonu i wtrysku do aktualnego składu paliwa.

\section{Opis systemu zasilania silnika}

W Katedrze Silników Spalinowych i Pojazdów ATH rozwijane są rozwiązania dotyczące wykorzystania paliw alternatywnych w ramach dwupaliwowego zasilania silników ZI. Pierwszym zastosowanym rozwiązaniem jest zamontowanie do kolektora dolotowego dodatkowych wtryskiwaczy do alkoholu, co wymaga zmian konstrukcyjnych kolektora [12]. Alter- 
solutions related to the use of alternative fuels in dual fueling systems in spark ignition engines. The first solution is fitting additional alcohol injectors in the intake manifold, which requires modifications to the intake manifold [12]. An alternative to the first two-injector solution is fuel mixing (gasoline and alcohol) upstream the fuel rail or in it. Such a solution should also ensure variable alcohol or gasoline shares in the range of $0 \%$ to $100 \%$ of the total fuel dose into the combustion chamber, depending on the engine operating conditions (engine speed and engine load) as well as its thermal state. The here presented solution is more universal compared with the two-injector system in the intake manifold. A prototype fuel mixer that is the essential part of the concept of dual fueling system was prepared for a four cylinder multipoint injected spark ignition engine - Fiat 1100 MPI (Fig. 2). The technical specifications have bee given in Table 1 .

In the Fiat 1100 MPI engine the injection pressure adjustment is realized through a valve located near the feeding pump. In this particular case the injection pressure regulatory valve is not located near the fuel rail. In the case of dual fueling when the fuels must be mixed under the conditions of working pressure (3.5 bar) in the injection system, the choke adjustment of the ratio of both fuels is strongly non-linear. An alternative to a choke adjustment is the control of fuel mixing through electromagnetic valves controlled by Pulse Width Modulation. In this case because of the possibilities of the control devices the pulses of 45 $\mathrm{Hz}$ were applied, generating the width of the pulse so that it was proportional to the measured fuel flow rate (in percent). Both electromagnetic valves were opened simultaneously. An interchangeable valve opening was not applied due to a lack of repeatability of the initial measurement results. In the prototype the fuels are fed to the mixing chamber through electromagnetic valves letting the fuels in the fuel rail. In the prototype of the mixer instead of specialized electromagnetic valves two typical LPG injectors were used, regularly fitted in FIAT Multipla. Both fuels were injected through these injectors to a special chamber where they are

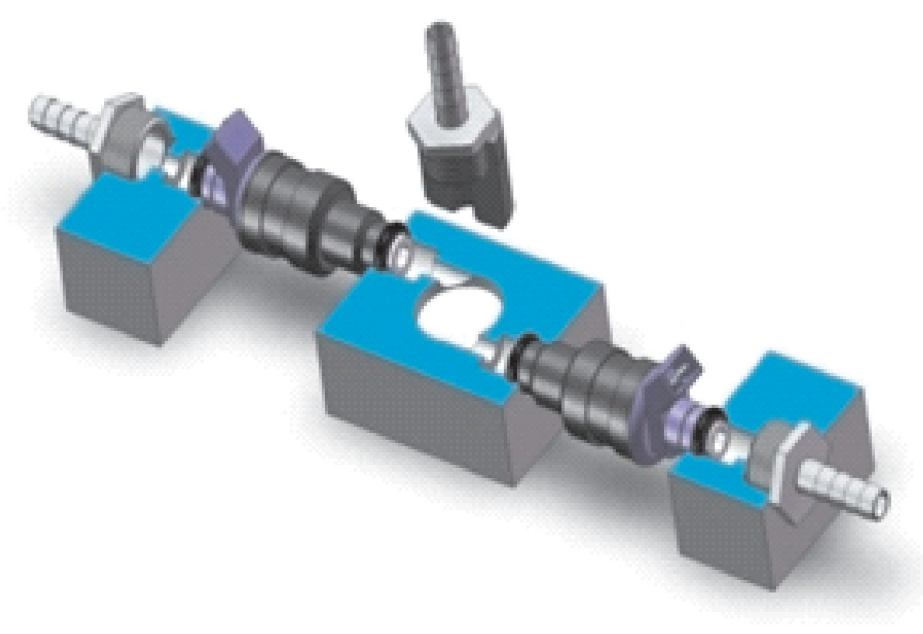

Fig. 3. Diagram of the fuel mixer

Rys. 3. Schemat ideowy mieszalnika paliw natywnym rozwiązaniem dla układu z dwoma kompletami wtryskiwaczy jest rozwiązanie polegające na mieszaniu paliw (benzyny i alkoholu) przed kolektorem paliwowym lub w kolektorze. Rozwiązanie to powinno również zapewnić zmienne udziały alkoholu lub benzyny w zakresie od $0 \%$ do $100 \%$ całkowitej dawki energii dostarczanej do silnika, zależnie od warunków pracy silnika (prędkości obrotowej $\mathrm{i}$ obciążenia) oraz jego stanu cieplnego. Przedstawione $\mathrm{w}$ pracy rozwiązanie jest bardziej uniwersalne w stosunku do kolektora dolotowego z dwoma kompletami wtryskiwaczy. Prototypowy mieszalnik paliw, który jest zasadniczym elementem koncepcji układu zasilania dwupaliwowego przygotowano dla 4-cylindrowego silnika o zapłonie iskrowym z wielopunktowym wtryskiem paliwa typ Fiat 1100 MPI (rys. 2). Dane techniczne silnika zamieszczono w tabeli 1 .

Table 1. Technical specifications of Fiat 1100 MPI engine

Tabela 1. Dane techniczne silnika Fiat 1100 MPI

\begin{tabular}{|l|c|}
\hline Engine type/typ silnika & Fiat 1100 MPI \\
\hline $\begin{array}{l}\text { Bore and stroke/średnica } \\
\text { cylindra } \times \text { skok }\end{array}$ & $70 \times 72 \mathrm{~mm}$ \\
\hline Displacement/pojemność skokowa & $1108 \mathrm{~cm}^{3}$ \\
\hline Compression ratio/stopień sprężania & 9.6 \\
\hline $\begin{array}{l}\text { Rated power/engine speed/moc } \\
\text { znamionowa/prędkośc obrotowa }\end{array}$ & $40 \mathrm{~kW} / 5000 \mathrm{rpm} /$ obr/min \\
\hline $\begin{array}{l}\text { Maximum torque/engine speed/ } \\
\text { maksymalny moment obrotowy/ } \\
\text { prędkość obrotowa }\end{array}$ & $88 \mathrm{~N} \cdot \mathrm{m} / 3000 \mathrm{rpm} /$ obr/min \\
\hline
\end{tabular}

W silniku Fiat 1100 MPI regulacja ciśnienia wtrysku realizowana jest za pomocą zaworu regulacyjnego znajdującego się w okolicy pompy zasilającej. Nie stosuje się tutaj zaworu regulacyjnego ciśnienia wtrysku umieszczonego przy kolektorze paliwowym. Przy zasilaniu dwoma paliwami, które muszą być mieszane w warunkach panującego ciśnienia roboczego (3,5 bar) w układzie wtryskowym, dławieniowa regulacja wzajemnego udziału obydwu paliw ma bardzo nieliniowy charakter. Alternatywą dla dławieniowej regulacji jest kontrola mieszania paliw za pomocą zaworów elekromagnetycznych sterowanych szerokością prostokątnego impulsu PWM (Pulse Width Modulation). W przypadku tego rozwiązania, z uwagi na możliwości aparatury sterującej, zastosowano impulsy o częstotliwości $45 \mathrm{~Hz}$, generując szerokość impulsu proporcjonalnie do mierzonego natężenia przepływu paliw (w skali procentowej). Obydwa zawory elektromagnetyczne otwierano jednocześnie. Przemiennego otwierania zaworów nie zastosowano z uwagi na niepowtarzalność wstępnych wyników pomiarów. W prototypie funkcjonalnym urządzenia paliwa dostarczane są do komory mieszania za pomocą zaworów elektromagnetycznych, umożliwiających doprowadzenie mieszaniny paliw do kolektora paliwowego. W prototypie mieszalnika zamiast specjalizowanych zaworów elektromagnetycznych wykorzystano dwa typowe wtryskiwacze z 
mixed. The preliminary investigations have shown that the throughput of the used injectors is sufficient even when the engine was fueled with pure methanol (the injector opening time is twice as long as compared to gasoline fueling). For the fuels to mix better in the outlet adaptor of the mixer a perlator strainer was used. In such a way homogenized fuel did not split in the time estimated for the injection of a required amount of fuel. The diagram of the mixer has been shown in Fig. 3 and the prototype mixer in Fig. 4.

\section{The test stand}

The tests on the prototype mixer were performed on an 'engineless' test bed. A prototype fueling system adapted from FIAT 1100 MPI was used. The system was equipped with a gasoline tank a methanol tank and a dual fuel consumption meter. Fig. 5 presents the view of the tanks including the turbine flow meters. Liquid fuel flow meters were used manufactured by AQUA METRO type VZO 4 and VZO 4 OEM of the following technical parameters:

- minimum fuel flow $\mathrm{Q}_{\min }-1 \mathrm{dm}^{3} / \mathrm{h}$, - maximum fuel flow $Q_{\text {nom }}-50 \mathrm{dm}^{3} / \mathrm{h}$.

The flow meters differed with the signal transmission and volume recording. In order to maintain a constant pressure of the mixed fuels in the fuel rail another pressure regulator was applied.

The diagram of the test bed has been presented in Fig. 6 .

For the feeding of the PWM injectors of the prototype mixer a controller was used developed in the Chair of Combustion Engines and Vehicles at the Technical University of Bielsko-Biala. The controller (KSSIP-3) can operate in

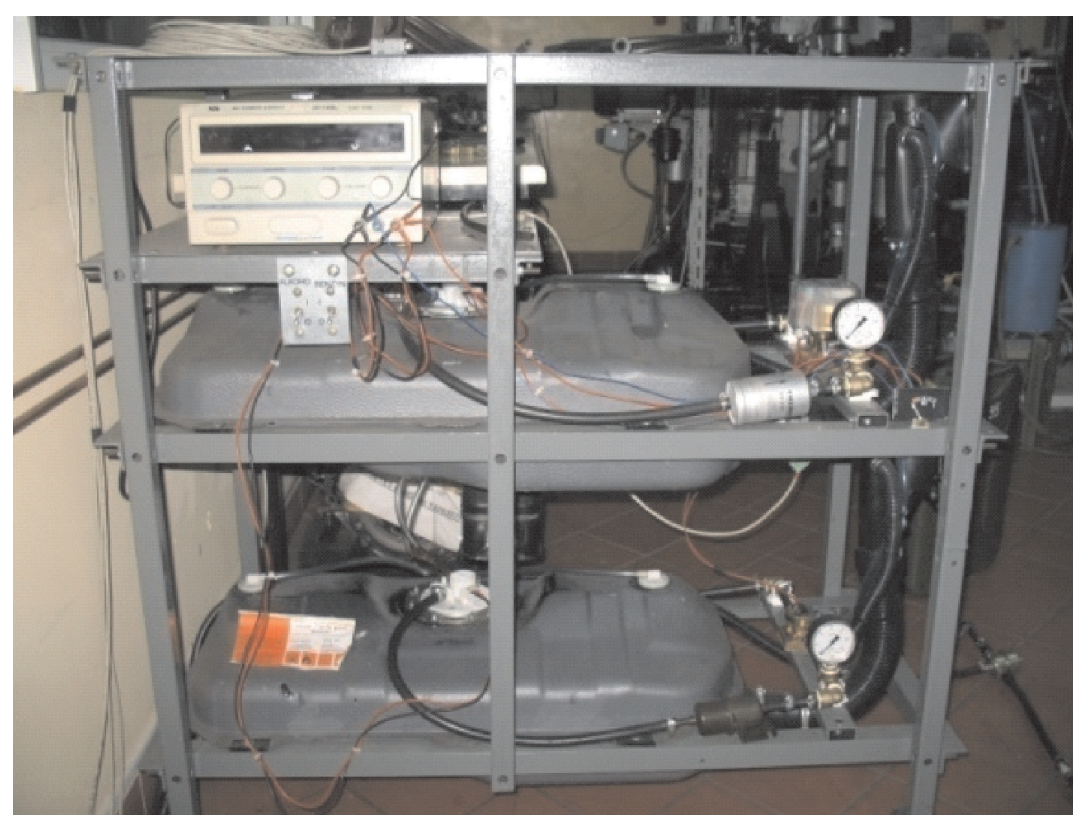

Fig. 5. The fuel supply system and the measurement system Rys. 5. Uktad zasilania paliwem wraz z uktadem pomiarowym zasilania gazowego, stosowane w silniku samochodu FIAT Multipla. Obydwa paliwa są wtryskiwane przez te wtryskiwacze do specjalnej komory, gdzie ulegają wymieszaniu. Badania wstępne wykazały, że wydatek zastosowanych

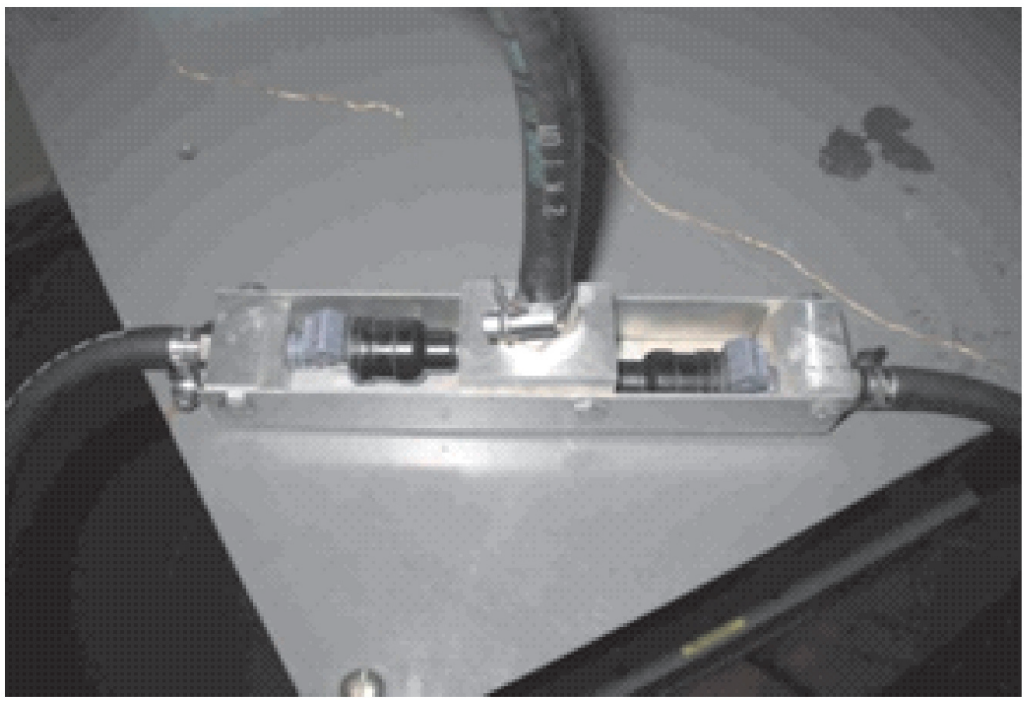

Fig. 4. The prototype of the fuel mixer

Rys. 4. Prototyp funkcjonalny mieszalnika paliw

wtryskiwaczy jest wystarczający nawet przy zasilaniu samym metanolem (czas otwarcia wtryskiwacza w przybliżeniu dwukrotnie dłuższy od czasu przy zasilaniu benzyną). W celu lepszego mieszania paliw w króćcu wylotowym mieszalnika zastosowano sito perlatora. Homogenizowane w ten sposób paliwo nie rozwarstwiało się w czasie przewidywanym dla wtrysku wymaganej objętości paliwa do silnika. Schemat ideowy mieszalnika przedstawiono na rys. 3 , a prototypowy mieszalnik paliw na rys. 4 .

\section{Stanowisko badawcze}

Badania prototypu mieszalnika wykonano na stanowisku bezsilnikowym. Wykorzystano w tym celu prototypowy układ zasilania silnika FIAT 1100 MPI stosowany na stanowisku hamownianym, wyposażony w zbiorniki metanolu i benzyny oraz podwójny układ pomiaru zużycia paliw. $\mathrm{Na}$ rysunku 5 przedstawiono zbiorniki paliwa wraz z przepływomierzami turbinowymi. Zastosowano przepływomierze paliw płynnych firmy AQUA METRO typ VZO 4 i VZO 4 OEM o następujących parametrach technicznych:

- minimalny wydatek paliwa $\mathrm{Q}_{\min }$ $1 \mathrm{dm}^{3} / \mathrm{h}$,

- maksymalny wydatek paliwa $\mathrm{Q}_{\text {nom }}$ $50 \mathrm{dm}^{3} / \mathrm{h}$.

Przepływomierze różniły się sposobem przesyłania sygnału i rejestracji objętości pomiarowej. W celu utrzymania stałego ciśnienia zmieszanych paliw występujących w rzeczywistym kolektorze paliwowym 
the mode allowing the control of the additional two electromagnetic valves operating at the frequency of $45 \mathrm{~Hz}$. In the regular mode the controller supervises synchronous operation of the engine fed with four MPI injectors.

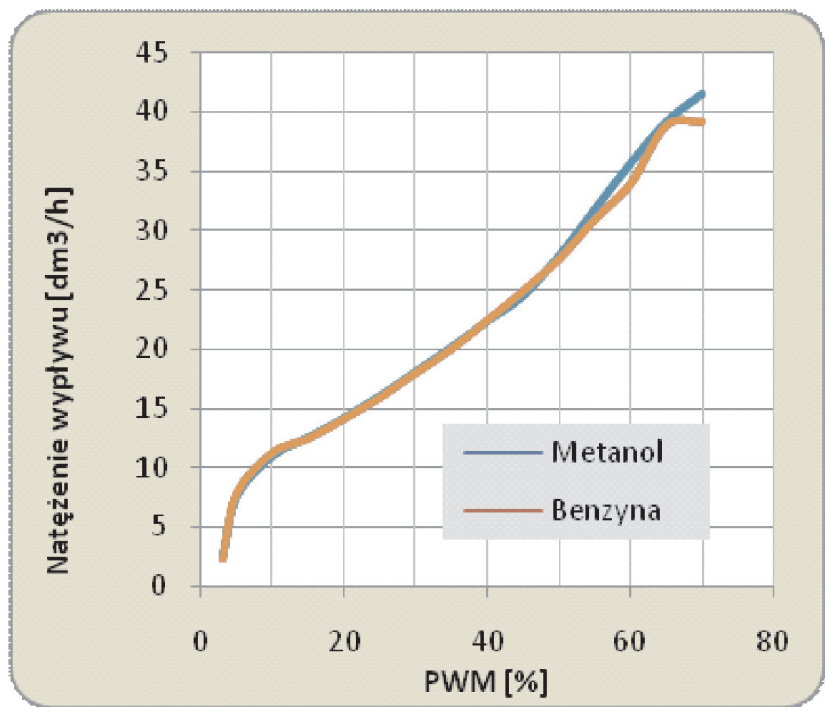

Fig. 7. Comparison of gasoline and methanol flow as a function of changes of the PWM pulse

Rys. 7. Porównanie wydatku benzyny i metanolu w zależności od rodzaju impulsu PWM

\section{Test results}

The basic purpose of the measurements was to determine the way of control of the electromagnetic valves in the mixer so that the selection of PWM (the extent of the pulse modulation set at the controller) of both electromagnetic valves secures the set methanol gasoline ratio. An additional

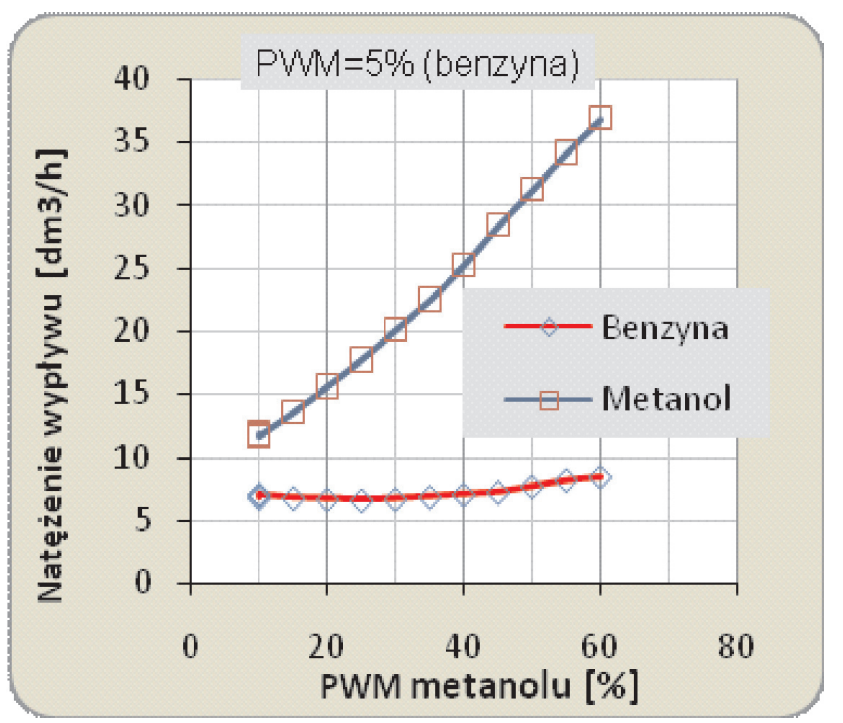

Fig. 8. Comparison of gasoline and methanol flow dependence on the PWM pulse: methanol pulse changes, gasoline pulse constant $5 \%$

Rys. 8. Porównanie wydatku benzyny i metanolu $w$ zależności od impulsu PWM: impuls dla metanolu zmienny, dla benzyny staty 5\%

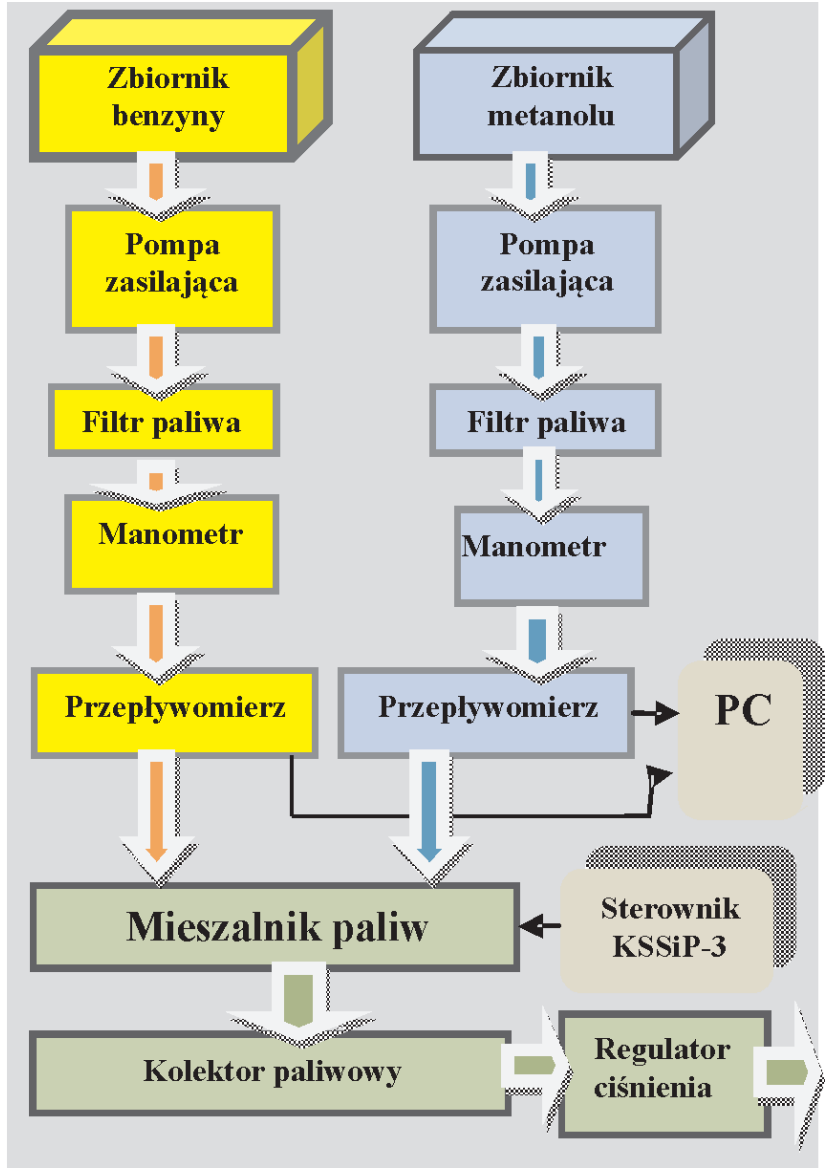

Fig. 6. Schematic diagram of the test bed Rys. 6. Schemat stanowiska badawczego

zastosowano dodatkowy regulator ciśnienia paliwa.

Schemat ideowy stanowiska badawczego przedstawiono na rys. 6.

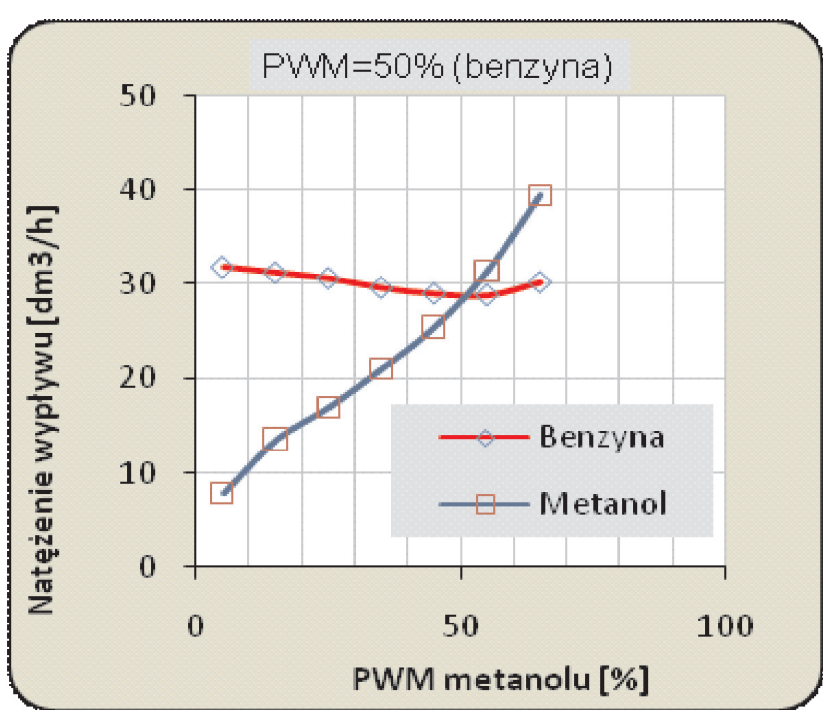

Fig. 9. Comparison of gasoline and methanol flow dependence on the PWM pulse: methanol pulse changes, gasoline pulse constant $50 \%$

Rys. 9. Porównanie wydatku benzyny i metanolu w zależności od impulsu PWM: impuls dla metanolu zmienny, dla benzyny staty $50 \%$ 


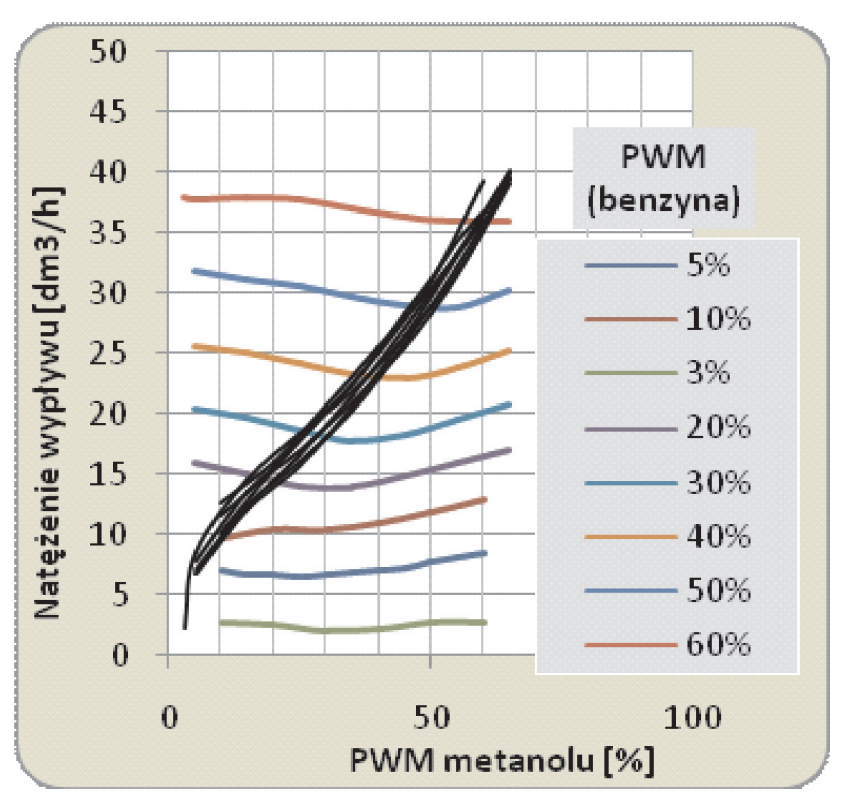

Fig. 10. Comparison of methanol flow for different PWM pulse for gasoline

Rys. 10 Porównanie wydatku metanolu dla różnych impulsów PWM dla benzyny o statych wartościach

purpose of the measurements was verification whether the control of the PWM of one electromagnetic valve influences the outflow rate of the fuel from the other electromagnetic valve. Fig. 7 presents the relation between the methanol and gasoline flow rate and the way of control at identical PWM values for both valves. Based on the presented characteristics we can state that at the same PWM pulse and simultaneous injection for both injectors the same fuel mass flows were obtained.

Figs 8 and 9 shows example changes in the outflow rate of methanol for different values of PWM for methanol at

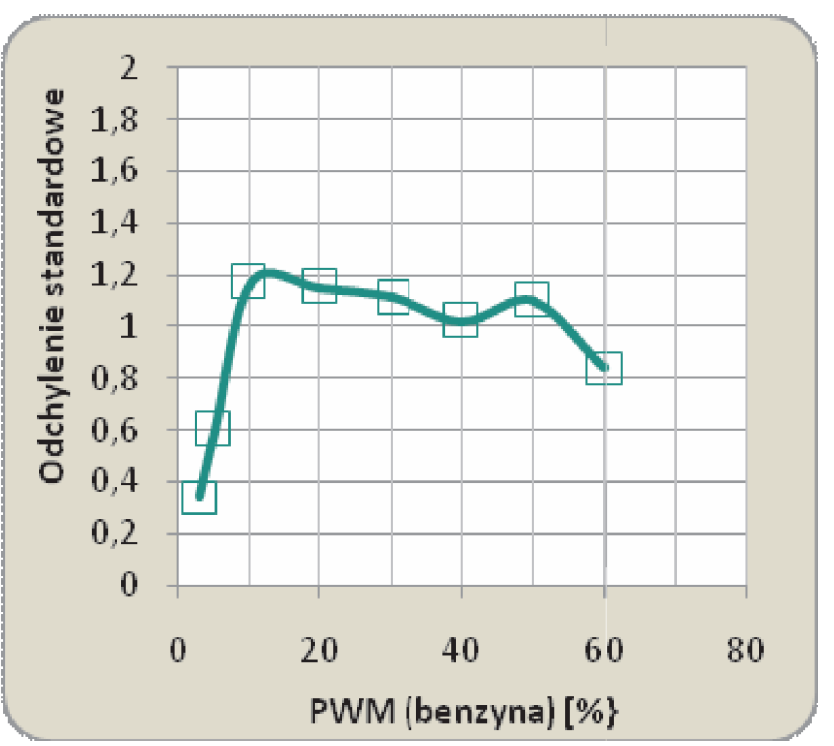

Fig. 11. Average standard deviation of gasoline flow for different PWM pulse for methanol

Rys. 11. Srednie odchylenie standardowe natężenia wyplywu benzyny dla różnych impulsów PWM dla metanolu
Do zasilania PWM wtryskiwaczy prototypowego mieszalnika zastosowano zaprojektowany w Katedrze Silników Spalinowych i Pojazdów ATH sterownik KSSIP-3, który posiada tryb pracy umożliwiający sterowanie dodatkowymi dwoma zaworami elektromagnetycznymi, pracującymi z częstotliwością $45 \mathrm{~Hz}$. W trybie podstawowym sterownik służy do sterowania synchronicznej pracy silnika zasilanego czterema wtryskiwaczami MPI.

\section{Wyniki badań}

Podstawowym celem przeprowadzonych pomiarów było określenie sposobu sterowania zaworami elektromagnetycznymi mieszalnika, tak aby dobór PWM (stopień wypełnienia impulsu zadawany na sterowniku) obydwu zaworów elektromagnetycznych umożliwiał otrzymanie założonego stosunku metanolu do benzyny. Dodatkowym celem pomiarów było również sprawdzenie, czy sterowanie impulsem PWM na jednym zaworze elektromagnetycznym ma wpływ na natężenie wypływu paliwa, na równocześnie otwieranym drugim zaworze elektromagnetycznym. Na rysunku 7 przedstawiono zależność natężenia przepływu benzyny i metanolu od sposobu sterowania przy tych samych wartościach PWM dla obydwu zaworów. Na podstawie przedstawionych charakterystyk można stwierdzić, iż przy tych samych impulsach PWM i równoczesnym wtrysku, dla obydwu wtryskiwaczy uzyskano jednakowe wydatki paliw.

Na rysunku 8 i 9 przedstawiono przykładowe zmiany natężenia wypływu metanolu dla różnych wartości PWM dla metanolu, przy stałych wartościach PWM dla benzyny wynoszących 5\% i 50\%. Zbiorczą ilustrację uzyskanych wyników pomiarów dla stałych wartości PWM benzyny i zmiennych wartości PWM metanolu przedstawiono na rys. 10. Widoczne rozbieżności charakterystyk natężenia wypływu metanolu wynikają z zastosowania w torze pomiarowym metanolu przepływomierza o mniejszej dokładności pomiarowej. Przedstawione charakterystyki uzasadniają tezę,

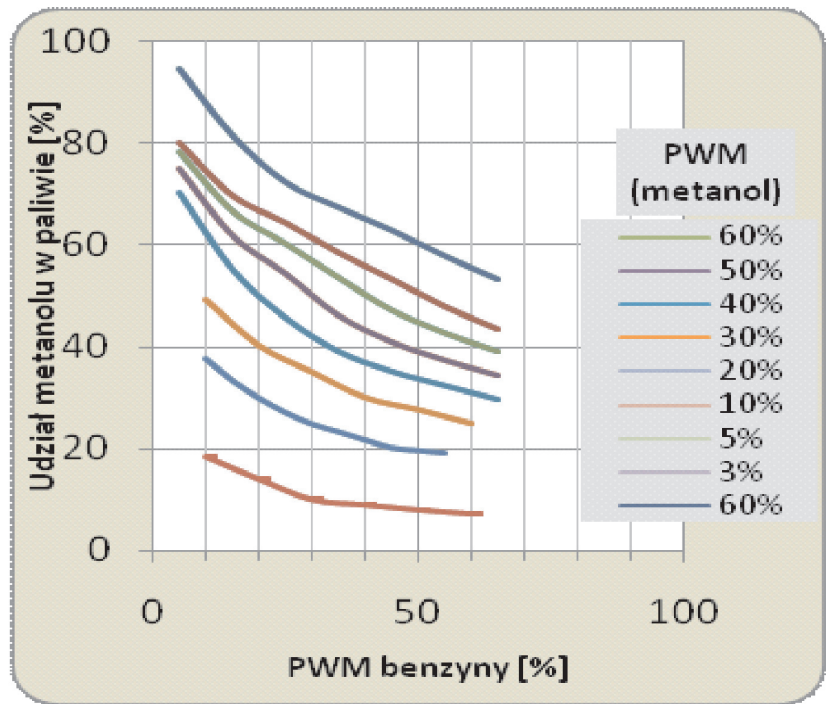

Fig.12. Comparison of methanol share for different gasoline and methanol PWM pulses

Rys. 12. Porównanie udziału metanolu dla różnych warunków sterowania benzyny $i$ metanolu 
constant values of PWM for gasoline $-5 \%$ and $50 \%$. The collective results of the measurements for constant PWM value for gasoline and variable values of PWM for methanol have been presented in Fig. 10. The visible divergence of the characteristics of outflow rate results from the application of a lower accuracy flow meter in the methanol measurement chain. The presented characteristics confirms the assumption that the control of one electromagnetic valve with a variable PWM pulse has little influence on the fuel outflow rate from the second electromagnetic valve controlled by a constant PWM pulse.

Figure 11 presents the average standard deviation of the fuel outflow rate for constant PWM values for methanol. We can see a small spread around the average of the outflow rate.

Figure 12 presents the changes in the share of alcohol content for variable PWM for the gasoline injector and constant PWM for the methanol injector. The changes in the opening times for the methanol injector in the tested range $\mathrm{PWM}=10 \div 50 \%$ resulted in the changes in the alcohol content in the range of $\mathrm{U}=18 \div 90 \%$. The obtainment of the range of change of the alcohol content $U=0 \div 100 \%$ is of course possible and can be done through injector control (limiting of PWM for gasoline). When controlling the mere injectors we can obtain any required alcohol content.

\section{Conclusions and final remarks}

The performed measurements and presented characteristics of the fuel mixer of dual fueled gasoline engines confirm the concept of such an engine fueling. They confirm the assumption that it is possible to feed homogenous fuel mixture directly to the fuel rail of the injection system significantly limiting the delay resulting from the change of the fuel composition fed to the cylinder. The adjustment of the fuel composition is also possible (gasoline and alcohol) depending on the level of PWM pulse modulation of the applied electromagnetic valves. The measurements were made for a constant PWM pulse frequency of $45 \mathrm{~Hz}$, yet with this type of fueling variable frequency should be used that results from the characteristics of the engine operation. The design of the prototype mixer with built-in counter injectors allows obtaining of an appropriate mixture of both mediums, which results from the application of the mixing chamber where swirling occurs. In the further stage of the investigations the authors plan to use a special mixer valve as shown in Fig. 13. Fig. 14 presents a diagram describing the operation of the said valve.

Based on the performed tests we can draw the following general conclusions:

The developed fueling system is characterized by a variety of features that are vital for dual fueling spark ignition systems.

Fig. 13. Electromagnetic valve for fuel mixing

Rys. 13. Elektromagnetyczny zawór mieszajacy dwa paliwa że sterowanie jednym zaworem elektromagnetycznym ze zmiennym impulsem PWM ma niewielki wpływ na natężenie wypływu paliwa z drugiego zaworu elektromagnetycznego sterowanego stałym impulsem PWM.

Na rysunku 11 przedstawiono średnie odchylenie standardowe natężenia wypływu benzyny dla stałych wartości PWM benzyny w czasie zmiany PWM metanolu. Widoczne jest niewielkie rozproszenie wokół średniej natężenia wypływu.

Na rysunku 12 przedstawiono zmiany udziału alkoholu przy zmianach PWM dla wtryskiwacza benzyny i dla stałych wartości PWM wtryskiwacza metanolu. Zmiany czasu otwarcia wtryskiwacza metanolu w badanym zakresie $\mathrm{PWM}=10 \div 50[\%]$ powodowały zmiany udziału alkoholu $\mathrm{W}$ zakresie $\mathrm{U}=18 \div 90[\%]$. Uzyskanie zakresu zmian udziału alkoholu $\mathrm{U}=0 \div 100 \%$ jest oczywiście możliwe i wynika ze sposobu sterowania wtryskiwaczami (ograniczenie PWM benzyny). Sterując tylko samymi wtryskiwaczami, można uzyskać dowolnie zadaną wartość udziału alkoholu.

\section{Podsumowanie i wnioski końcowe}

Wykonane pomiary i przedstawione charakterystyki mieszalnika paliw przeznaczonego do dwupaliwowego zasilania silnika o zapłonie iskrowym potwierdzają koncepcję takiego sposobu zasilania silnika. Uzasadniają tezę, że możliwe jest doprowadzenie homogenicznej mieszaniny paliw bezpośrednio do kolektora paliwowego układu wtryskowego, ograniczając w znacznym stopniu zwłokę wynikającą ze zmiany składu paliwa doprowadzonego do cylindra. Możliwa jest również regulacja składu paliwa (benzyny i alkoholu) w zależności od stopnia wypełnienia impulsów PWM zastosowanych zaworów elektromagnetycznych. Pomiary wykonano dla stałej częstotliwości impulsów PWM wynoszącej $45 \mathrm{~Hz}$, jednak przy takim sposobie zasilania silnika powinna być zastosowana zmienna częstotliwość, wynikająca $\mathrm{z}$ charakterystyki pracy silnika. Konstrukcja prototypowego mieszalnika z wbudowanymi wtryskiwaczami przeciwprądowo pozwala uzyskać odpowiednią mieszaninę obydwu mediów, co wynika z zastosowania komory mieszającej, powodującej zawirowanie mieszanki. W następnym etapie badań przewiduje się zastosowanie specjalnego zaworu mieszającego przedstawionego na rys. 13, wraz ze schematem działania przedstawionym na rys. 14 .
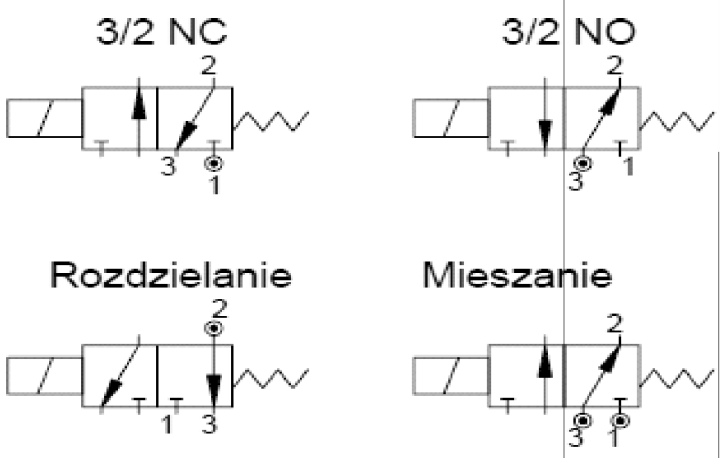

Fig. 14. Diagram presenting the operation of the electromagnetic valve Rys. 14. Schemat działania zaworu elektromagnetycznego 
Some of these features are:

- engine startup on gasoline only, which preserves the engine startup specific properties as in traditional systems;

- burning gasoline and any type of alcohol at actively variable alcohol content depending on engine load and speed;

- splitting has been eliminated at high alcohol content;

- switching to pure alcohol fueling while the engine is operating.

Alcohol fueling enables a substantial reduction of the emission of $\mathrm{NO}_{\mathrm{x}}$ and hydrocarbons and an improvement in the general efficiency and external engine parameters such a power output and maximum torque.

The external parameters of the engine can further be improved through an increase in the compression ratio and engine tune-up.

Paper reviewed/Artykut recenzowany
Na podstawie przeprowadzonych badań można wyciągnąć następujące wnioski o charakterze ogólnym:

Opracowany system zasilania charakteryzuje się wieloma zaletami istotnymi przy dwupaliwowym zasilaniu silnika ZI. Do zalet tych należą:

- możliwość rozruchu silnika na samej benzynie, co pozwala zachować jego właściwości rozruchowe jak przy zasilaniu tradycyjnym;

- możliwość równoczesnego spalania benzyny i dowolnego alkoholu, przy aktywnie zmienianym udziale alkoholu zależnie od obciążenia i prędkości obrotowej silnika;

- wyeliminowanie zjawiska rozwarstwiania się mieszanin benzyna-alkohol przy dużych udziałach alkoholu;

- możliwość przechodzenia na zasilanie samym alkoholem podczas pracy silnika.

Zasilanie alkoholem daje istotne możliwości zmniejszenia emisji tlenków azotu i węglowodorów oraz poprawy sprawności ogólnej i parametrów zewnętrznych silnika, takich jak moc i maksymalny moment obrotowy.

Parametry zewnętrzne silnika mogą być dalej podwyższane przez zwiększenie stopnia sprężania silnika oraz optymalizację jego regulacji.

\section{Bibliography/Literatura}

[1] Baczewski K., Kałdoński T.: Paliwa do silników o zapłonie iskrowym. WKiŁ 2005.

[2] Stell Lexikon, Folge 30, MTZ nr 12/1997.

[3] Kotowski W., Klimiec J., Marcjasz-Siemiątkowski I.: Możliwości wykorzystania metanolu i jego pochodnych jako paliw silnikowych. Przemysł Chemiczny nr 80/1/2001.

[4] Metanol/gasoline blends and emissions. Automotive Engineering nr 4/1992 (cz. 1), nr 5/1992 (cz. 2).

[5] Mayer L.: Etanol jako komponent benzyn silnikowych. Auto Technika Motoryzacyjna nr 6/1992 (kwartalnik N-T II/1992).

[6] Bednarek E., Małyska J., Kosowicz L.: Wykorzystanie alkoholu etylowego w paliwach silnikowych reformułowanych. Przemysł Chemiczny nr 76/3/1997.

[7] Clarke 1.: Waste not, want not. Engine Technology International nr $1 / 2003$.

[8] Maćkowski J.: Emisja aldehydów z silników o ZI zasilanych paliwami zawierającymi związki tlenowe. Paliwa, Oleje i Smary w Eksploatacji nr 91/2001 (cz. 1), nr 92/2001 (cz. 2).

[9] Frączek K., Rzeczkowski S., Chojecki J., Ciok J.: Eter etylotert-butylowy wysokojakościowy komponent benzynowy z surowca odnawialnego. Przemysł Chemiczny, nr 82/5/2003.
[10] biopaliwa.com

[11] www.atcobr.pl

[12] Stelmasiak Z., Larisch J., Semikow J.: Badania wstępne dwupaliwowego silnika o zapłonie iskrowym zasilanego alkoholem metylowym i benzyną. Silniki Spalinowe nr 3/2008.

[13] Stelmasiak Z., Larisch J., Semikow J.: Analiza wybranych parametrów spalania dwupaliwowego silnika o zapłonie iskrowym zasilanego alkoholem i benzyną. Silniki Spalinowe nr $1 / 2009$.

[14] Stelmasiak Z., Larisch J., Semikow J.: Some aspects of bifuel SI engine run on alcohol and gasoline, 12th EAEC European Automotive Congress Bratislava 2009.

[15] Stelmasiak Z., Semikow J.: The possibilities of impovement of spark ignitron engine efficiency trough dual fuelling of methanol and gasoline, Combustion Engines 3/2010.

[16] Stelmasiak Z.: Możliwości dwupaliwowego zasilania benzyną i alkoholem silników o zapłonie iskrowym, Logistyka nr $6 / 2010$.

[17] rb-kwin.bosch.com /en/powercomsumptionemissions /.../ flexfuel
Jerzy Larisch, DEng. - doctor in the Faculty of Mechanical Engineering at University of Bielsko-Biala.

Dr inż. Jerzy Larisch - adiunkt na Wydziale Budowy Maszyn i Informatyki Akademii Techniczno-Humanistycznej w Bielsku-Biatej.

e-mail: jlarisch@ath.bielsko.pl

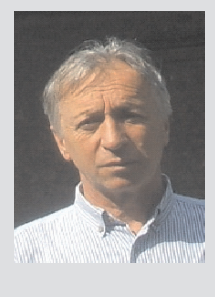

Zdzisław Stelmasiak, DSc., DEng. - Professor in the Faculty of Mechanical Engineering at University of Bielsko-Biala.

Dr hab. inż. Zdzisław Stelmasiak - profesor na. Wydziale Budowy Maszyn i Informatyki Akademii Techniczno-Humanistycznej w Bielsku-Białej.

e-mail: zstelmasiak@ath.bielsko.pl

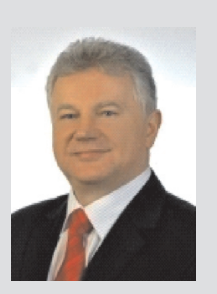

